Abstracta Iranica Abstracta Iranica

Revue bibliographique pour le domaine irano-aryen

Volume 27 | 2006

Comptes rendus des publications de 2004

Women in Iran. From 1800 to the Islamic Republic. Urbana \& Chicago, University of Illinois Press, 2004, 288 p. Chronologie, index.

Azadeh Kian-Thiébaut

(2) OpenEdition

Journals

Édition électronique

URL : http://journals.openedition.org/abstractairanica/6048

DOI : 10.4000/abstractairanica.6048

ISSN : 1961-960X

Éditeur :

CNRS (UMR 7528 Mondes iraniens et indiens), Éditions de l'IFRI

Édition imprimée

Date de publication : 15 mai 2006

ISSN : 0240-8910

Référence électronique

Azadeh Kian-Thiébaut, «Women in Iran. From 1800 to the Islamic Republic. Urbana \& Chicago, University of Illinois Press, 2004, 288 p. Chronologie, index. », Abstracta Iranica [En ligne], Volume 27 | 2006, document 215, mis en ligne le 02 janvier 2007, consulté le 25 septembre 2020. URL : http://

journals.openedition.org/abstractairanica/6048; DOI : https://doi.org/10.4000/abstractairanica.6048

Ce document a été généré automatiquement le 25 septembre 2020.

Tous droits réservés 


\title{
Women in Iran. From 1800 to the Islamic Republic. Urbana \& Chicago, University of Illinois Press, 2004, 288 p. Chronologie, index.
}

\author{
Azadeh Kian-Thiébaut
}

Cet ouvrage collectif tente de brosser le portrait de la condition et du statut des femmes iraniennes pendant les deux derniers siècles. Certaines contributions sont inédites, d'autres constituent des versions plus ou moins remaniées de textes déjà publiés. De ce fait, il manque d'originalité pour les lecteurs spécialisés mais il est susceptible d'intéresser les lecteurs profanes.

\section{INDEX}

Thèmes : 4.3. Histoire de l'Iran moderne (à partir de 1905)

\section{AUTEURS}

AZADEH KIAN-THIÉBAUT

CNRS - Paris 